\title{
Abilify- Induced Gambling Disorder: A Case Review
}

\author{
Thersilla Oberbarnscheidt*1, Miller NS ${ }^{2}$ and Henry JG ${ }^{3}$ \\ ${ }^{1}$ Department of Psychiatry, Central Michigan University, USA \\ ${ }^{2}$ Medical College of Georgia, Dept. Of Psychiatry, CEO of Health Advocates PPLC, USA \\ ${ }^{3} J o n a t h a n$ G. Henry, Community Mental Health of Central Michigan, USA
}

Submission: November 28, 2017; Published: December 04, 2017

*Corresponding author: Thersilla Oberbarnscheidt, Central Michigan University, Department of Psychiatry 1000 Houghton Avenue, Saginaw, MI 48602, USA, Email: Oberb1t@cmich.edu

\begin{abstract}
Objective: Describe the clinical course, correlation and risk of Abilify- induced gambling disorder.

Method: Case Report

Results: This case is an additional case documentation pointing out the risk of the dopamine partial agonist to cause or exacerbate a gambling disorder.

Conclusion: Patients when started on Abilify should be monitored closely for developing Gambling disorder even if they are naïve to gambling. Without directly addressing and discussing gambling behaviours with the patient, the problem can be easily missed and result in a financial disaster for the patient. Collateral information may be essential in identifying the problem. Abilify dose should be lowered of even discontinued.
\end{abstract}

Keywords: Abilify; Gambling Disorder; Addiction; Impulsive behaviours

\section{Introduction}

Abilify or in its generic form Aripriprazole is an atypical antipsychotic. It is used frequently for the treatment of psychosis in schizophrenic patients, as mood stabilizer in patients with bipolar disorder or as an augmenting agent in the treatment of major depressive disorder [1,2]. Abilify is a D2 partial agonist with high D2 receptor affinity. Positive symptoms of schizophrenia can be reduced by reduction of $\mathrm{D} 2$ hyperactivation in the mesolimbic pathway but at the same time remain enough D2 receptor stimulation in the mesocortical pathway and in the nigrostriatal pathway to prevent negative symptoms as well as extrapyramidal side effects [1]. The FDA issued a black box warning about new-impulse problems with Abilify in May 2016 [2].

Gambling disorder according to the DSM V is a persistent or recurrent problematic gambling behaviour leading to clinically significant impairment or distress [3]. It is classified as an addictive behaviour. Several risk factors are recognized for the development of gambling disorder, one of them being medications. Dopamine replacement therapy has been identified as well as Abilify which is receiving growing attention [4-9].

\section{Case Presentation}

The patient is a $47 y$ r Caucasian male who was seen in the outpatient clinic for management of schizoaffective disorder bipolar type. The patient was started on Abilify due to treatment failure on Invega. Other previous medications include Pristiq, Tegretol, Wellbutrin, Seroquel, and Trazodone. The patient had been with the same Psychiatrist for the last 6 years. The patient had been struggling with tobacco and cannabis use. At the time of start of medication, he was not actively using cannabis but still smoking tobacco about 1 pack per day. Patient did not have any history of pathological gambling prior to the initiation of Abilify. The patient presented hippomanic at the time of evaluation. The starting dose of the Abilify was $5 \mathrm{mg}$ daily per os. The patient was followed up closely and the Abilify was increased to $10 \mathrm{mg}$ daily after the 4 weeks follow up visit when the patient continued to present hippomanic. He reported insomnia, racing thoughts, increased impulsivity, and pressured speech. He was able to continue to follow along with his daily activities.

He consecutively over the next 2 months started to develop gambling problems. He stated that shortly after the start of 
Abilify he started to visit the local casino. This habit increased in intensity and frequency and over the next 2 months and the patient developed substantial debt. The patient stated that he would have days too when he stays in bed all day and did not have energy to do anything. He further reported that his weight and appetite were unchanged. He denied homicidal or suicidal ideations. He denied any perceptual abnormalities at this point. The patient continued to smoke cigarettes and tobacco. He had the nicotine patch and lozenges available but was not yet ready to quit. The gambling disorder was not identified as a new diagnosis right away since the patient did not reveal this information during the first follow up visits. Once the financial difficulties and debt could no longer be hidden, it became obvious. His wife asked the patient to accompany him to his medication review visits and revealed the gambling behaviours. As a result, Abilify was stopped immediately. The patient was started on Depakote after this episode and referred to a gambling disorder treatment group within the agency. The patient stopped gambling completely after this treatment intervention and has been followed for 6 month currently.

\section{Discussion}

The link between gambling disorder and the treatment with Abilify has been pointed out for several years but it is important to recognize that this adverse reaction continues to be an ongoing problem [4-9]. This case report is adding on to the already published case reports and is designed sensitize the treating physician to assess and monitor the patient for addictive behaviours. The use of screening tools might be helpful to identify the gambling disorder early on, for example with the Diagnostic Screen for Gambling Problems-Self Administered [10]. Additional compulsive behaviours in form of compulsive eating or sex have been reported as well [4-6]. Patients with additional risk factors for the development of gambling disorder should especially follow closely. Risk factors include previous substance use disorders, bipolar disorder or impulsive personalities. Physicians need to be educated and warned about this correlation. Only a few case reports about Abilify induced gambling disorder have been published and the association about Abilify with impulse control disorders has not been scientifically researched regarding its pathos-mechanism [4-9].

\section{Conclusion}

This case reports underlines the continuous importance to monitor patients for pathological gambling behaviours after the initiation of Abilify. The new impulse control problems are rare but may result in severe harm to the patient. If not addressed properly the gambling behaviours can easily be missed. Further research is needed regarding the path mechanism of Abilify and impulse control problems including gambling addiction.

\section{References}

1. Otsuka Pharmaceutical Co, Ltd. Tokyo, Japan, 101-8535.

2. Food and Drug Administration, FDA. gov, USA.

3. Diagnostic and Statistical Manual of Mental Disorders, DSM 5, ( $5^{\text {th }}$ Edn) (2013) American Psychiatric Association, USA.

4. Mete D, Dafreville C, Paitel V, Wind P Aripiprazole (2016) gambling disorder and compulsive sexuality, Encephale 42(3): 281-283.

5. Gavaudan G, Magalon D, Cohen J, Lancon C, Leonetti G, et al. (2010) Partial agonist therapy in schizophrenia: relevance to diminished criminal responsibility. J Forensic Sci 55(6): 1659-1662.

6. Roxanas MG (2010) Pathological gambling and compulsive eating associated with aripiprazole. Aust N Z J Psychiatry 44(3): 291.

7. Cohen J, Magalon D, Boyer L, Simon N, Christophe L et al. (2011) Aripiprazole-induced pathological gambling: a report of 3 cases. Curr Drug Saf 6(1): 51- 53.

8. Smith N, Kitchenham N, Bowden Jones H (2011) Pathological gambling and the treatment of psychosis with aripiprazole: case reports. Br J Psychiatry 199(2): 158- 159.

9. Gaboriau L, Victorri Vigneau C, Gerardin M, Allain-Veyrac G, JollietEvin P, et al. (2014) Aripiprazole: a new risk factor for pathological gambling? A report of 8 case reports. Addict Behav 39: 562- 565.

10. National Council on Gambling Problem, NORC- Diagnostic Screen For Gambling Problems-Self Administered (NODS-SA).

\section{Your next submission with Juniper Publishers will reach you the below assets}

- Quality Editorial service

- Swift Peer Review

- Reprints availability

- E-prints Service

- Manuscript Podcast for convenient understanding

- Global attainment for your research

- Manuscript accessibility in different formats

( Pdf, E-pub, Full Text, Audio)

- Unceasing customer service

Track the below URL for one-step submission

https://juniperpublishers.com/online-submission.php 